\title{
Subject Reference End Date
}

National Cancer Institute

\section{Source}

National Cancer Institute. Subject Reference End Date. NCI Thesaurus. Code C158690.

The date a subject reference period has concluded. 